DOI: $10.14746 /$ por.2018.1.12

\title{
LUDO-ŻERCY DOBRO-CZYŃCY. KARL KRAUS I ELFRIEDE JELINEK
}

\author{
Monika SzcZepaniaK ${ }^{1}$ \\ (Uniwersytet Kazimierza Wielkiego w Bydgoszczy)
}

Słowa kluczowe: Karl Kraus, Elfriede Jelinek, satyra, język, intertekstualność, autorstwo

Key words: Karl Kraus, Elfriede Jelinek, satire, language, intertextuality, authorship

\begin{abstract}
Abstrakt: Monika Szczepaniak, LUDO-ŻERCY DOBRO-CZYŃCY. KARL KRAUS I ELFRIEDE JELINEK. „PORÓWNANIA” 1 (22), 2018. T. XXII, S. 219-236. ISSN 1733-165X. Artykuł stanowi próbę porównania poetologii reprezentowanych przez austriackich pisarzy satyrycznych Karla Krausa i Elfriede Jelinek z uwzględnieniem kontekstów kulturowych, w których osadzona jest ich twórczość. Punktem wyjścia dla przeprowadzonej analizy tekstów „satyryków apokaliptycznych" jest esej Waltera Benjamina Karl Kraus, który wskazuje na kanibaliczne źródła satyry (satyryk jako "figura, w której cywilizacja recypowała ludożercę"). Figura ludożercy w znaczeniu metafory opisującej strategie produkcji tekstu, metody krytyki języka oraz koncepcje autorstwa staje się kategorią analityczną i narzędziem interpretacji.
\end{abstract}

\begin{abstract}
Monika Szczepaniak, MAN-EATERS AND DO-GOODERS. KARL KRAUS AND ELFRIEDE JELINEK. "PORÓWNANIA" 1 (22), 2018. Vol. XXII, P. 219-236. ISSN 1733-165X. The object of the present study is to compare the poetological concepts represented by Austrian satirical writers Karl Kraus and Elfriede Jelinek, considering the cultural contexts of their work. The starting point for the analysis of the texts by the "apocalyptic satirists" is the essay by Walter Benjamin Karl Kraus, pointing to the cannibalistic origin of the satire (the satirist as "the figure in whom the cannibal was received into civilisation"). The figure of the cannibal becomes an analytic category as a metaphor describing strategies of text production, methods of language criticism as well as conceptions of authorship.
\end{abstract}

1 E-mail: monika.szczepaniak@ukw.edu.pl 
Pisarz powinien burzyć frazesy,

a jeśli przetrwają dzieła z naszych czasów,

to będa to te nieliczne pozbawione frazesów.

(Bachmann 297) $)^{2}$

\section{Dyskurs i dys-kurs}

Istotą austriackości jest wątpienie w rzeczywistość realną i wiara w rzeczywistość językową. Między austriackim sceptycyzmem a austriacką akrybią językową istnieje bezpośredni związek przyczynowy: zadaniem rzeczywistości werbalnej jest udoskonalanie, korygowanie, zawstydzanie rzeczywistości realnej [...] (Eisenreich 107).

Jedną z głównych podstaw sformułowanej w 1962 roku diagnozy eseisty Herberta Eisenreicha o konstytutywnej dla literatury austriackiej zasadzie „twórczej nieufności" stanowiła wielka austriacka tradycja wiwisekcji rzeczywistości nierozerwalnie połączona z krytyczną analizą języka oraz apokaliptyczną wizją świata, tradycja wyznaczona przez jej wybitnych (męskich) przedstawicieli z Johannem Nestroyem $^{3}$ i Karlem Krausem na czele. W latach siedemdziesiątych XX wieku $\mathrm{w}$ „kraju satyry” (por. Benay, Stieg) do panteonu pisarzy „kalających własne gniazdo" weszła autorka wyposażona $\mathrm{w}$ "złe spojrzenie" (Burger), uprawiająca estetykę agresywnego „uderzania siekierą" ${ }^{4}$, okrzyknięta skandalistką, prowokatorką, femme terrible sceny literackiej i teatralnej - Elfriede Jelinek. W 1993 roku w jednym z wywiadów autorka tak zdefiniowała swoją estetykę:

[S]ednem mojej strategii pisarskiej jest zasada negatywności - satyryczne zniekształcanie rzeczywistości, jej przesadne uwypuklanie, bo rzeczywistość jest po prostu straszna. Podstawowym impulsem mojego pisarstwa są złość i wściekłość - tego nie mogę zmienić (Berka 129).

W innym wywiadzie, spoglądając wstecz na swoją twórczość, także nie pozostawiła wątpliwości co do tradycji, w jakiej należy sytuować jej powieści, teksty dla te-

2 Wszystkie cytaty - jeśli nie zaznaczono inaczej - w tłumaczeniu autorki - M.S.

3 Karl Kraus napisał esej Nestroy und die Nachwelt i nazwał Nestroya pierwszym satyrykiem, w którego tekstach ",język myśli o rzeczach" (Kraus 1912: 12). Także Jelinek napisała esej poświęcony Nestroyowi O graniu siebie za pomoca jezzyka. Jego pierwsze zdanie znakomicie opisuje jej własną estetykę: „Nestroy jest autorem, który lubi grać, gra siebie (właśnie tak: siebie) z pomocą języka, do którego najpierw wkłada siebie, a następnie wyjmuje. Wciska się do wnętrza, rzuca po trochu słowami i zdaniami, a potem każe im przestać. One z kolei mówią bez ogródek: co się stało i że gdzieś coś zostało przerwane" (Jelinek 2012e: 182).

4 Por. słynny cytat: „Uderzam siekierą w sam środek, aby w miejscach, gdzie pojawiły się postaci z moich dramatów, nigdy już nie urosła trawa" (Jelinek 1984: 14). 
atru i eseje: „Moja wczesna proza jest wyraźnie eksperymentalna. Poza tym jestem kontynuatorką tradycji Karla Krausa i Eliasa Canettiego, która została unicestwiona przez nazizm lub znajduje się w stadium wymierania" (Hofmeister 109). Jelinek zwraca uwagę na żydowskie korzenie tego rodzaju pisarstwa, które sama reprezentuje, a którego podstawą jest wiara w słowo („,że słowo powie wszystko" (Berka 138)) i jednocześnie nieufność wobec każdego pojedynczego słowa. Elementem tej tradycji jest także specyficzne poczucie humoru, idące $\mathrm{w}$ parze $\mathrm{z}$ powagą, opartą na przekonaniu, że współczesność została naznaczona katastrofami z przeszłości („pisanie poezji z pominięciem Auschwitz jest niemożliwe” (Berka 137)).

Kraus i Jelinek - satyrycy apokaliptyczni ${ }^{5}$, mistrzowie sarkastycznego cytatu i cynicznego komentarza, artyści przesady, geniusze gry językowej. Uprawiają satyrę totalną, przemawiają z pozycji społecznego zaangażowania, poruszają wiele wspólnych tematów, reagują na aktualne wydarzenia, piętnują medialne uzurpacje, symulacje, deformacje, kompromitacje. Są w swoim żywiole, kiedy burzą frazę, przytaczają obce pismo, obnażają zakłamanie języka. Według Krausa potrzebny jest tylko cudzysłów, by to, co „niewysłowione”, wypowiedziało się samo: „najbardziej jaskrawe wymysły pisarza są cytatami” (Kraus 1991) zykowi, aby mógł mówić sam: „Mowa mówi o sobie [Die Rede ist von sich selbst]” (Jelinek 2013b). Modus negatywności leżący u podstaw techniki cytowania wyraża fragment eseju Jelinek o charakterze aforystycznym (to samo mógłby napisać Kraus): „Moje powtórki mówienia, moje pomówienia [Ich lasse nachreden, aber es ist eine schlechte Nachrede]" (Jelinek 2013b). Kraus i Jelinek kreują autonomiczne enklawy w polu literackim i medialnym - przestrzenie zapewniające intelektualną i artystyczną niezależność, które można określić mianem „, anty-mediów": satyryczno-polemiczne czasopismo „Die Fackel” (gdyby Jelinek żyła w czasach Krausa, prawdopodobnie redagowałaby własną "Pochodnię") ${ }^{8}$, autorska strona internetowa www.elfriedejelinek.com (Kraus publikowałby on-line). Łączy tę parę pisarzy, eseistów, krytyków kultury, proroków kresu ludzkości last but not least specyficzny mechanizm recepcji, zobrazowany przez Jelinek w Podróży zimowej w postaci „osobliwej staruszki”, która „nawija to samo, w kółko to samo" - wyśmiewana przez rozbawiony tłum imaginujący jej zniknięcie w lodowatej wodzie wraz ze zdartą moralizatorską śpiewką:

Co to za język, jakim językiem pani mówi? Kto to ma zrozumieć? Czym on w ogóle jest, ten pani język, co to ma być, wszystko z drugiej, trzeciej ręki!, bo pani własne ręce są do

5 Edward Timms użył tego określenia w odniesieniu do Krausa.

6 Cyt. ze wstępu (strona nienumerowana): „die grellsten Erfindungen sind Zitate”.

7 Por. np. rozmowa z Sigrid Berką (Berka 129). W eseju poświęconym Nestroyowi czytamy: ,język mówi samym sobą i ze sobą samym, a gdy ktoś próbuje przy nim manipulować, on natychmiast chowa się do swojej skorupy jak ślimak" (Jelinek 2012e: 182).

8 Być może satyryczna wyobraźnia, poczucie humoru i chęć „przedrzeźniania” językowych wzorców podyktowałyby autorce zmodyfikowany tytuł „Die Fuckel”. 
niczego, co to za bełkot, co to za dyrdymały puszcza pani w świat, bo że pani chce, żeby się pałętały, tego się domyślamy, ale co możemy na to poradzić? (Jelinek 2013a: 202).

W gruncie rzeczy analogiczną diagnozę wyraża aforystyczny język Krausa w obrazie ornitologicznej transformacji: „Ptak, który własne gniazdo kala, zamienia się w ptaka, którego własne gniazdo kala” (Kraus 1928: 5).

Kraus - „jeden z wczesnych stylistów intertekstualności” (Pizer 502) - demonstruje oryginalną metodę demaskatorskiego cytowania. Przyświeca mu ambicja gigantycznej korekty uniwersum: oczyszczenia z korupcji, zakłamanego dziennikarstwa („Journalie”), kapitalizmu, militaryzmu, wreszcie przemiany języka - tej skorumpowanej „nierządnicy” - w niewinną „dziewicę” (Kraus 1987: 540)9 , powrotu do „praźródła” (Ursprung) jako skarbnicy kreatywności artystycznej oraz norm etycznych, obrony poetyki autentyczności i oryginalności przed innowacyjnymi naleciałościami stylu modernistycznego ${ }^{10}$. Jelinek uprawia „hermeneutykę cytowania” (Steiner 21) inspirowaną agresywną satyrą Krausa, nie podziela jednak purystycznej filozofii języka, sugerującej możliwość restauracji jego czystej formy. Kraus tworzy estetyczną harmonię, suwerennie panuje nad materią języka, formułuje autorytarne komentarze, próbuje uzyskiwać holistyczny ogląd, oddzielać dobro od zła, prawdę od fałszu, informację od sztuki, "język" od "gazety"11. Istotą twórczości Jelinek jest zdezintegrowany, heterogeniczny słowotok podszyty zwątpieniem $\mathrm{w}$ istnienie spójnego świata $\mathrm{z}$ jednoznacznymi kryteriami podziałów („Babel w jednym języku” (Derrida 2000: 33)). Mentorski dyskurs Krausa ma charakter argumentacji linearnej z wpisaną weń sugestią nieomylności, podczas gdy Jelinek walczy z każdą językową kreacją jednoznaczności, tworzy rizomatyczną tkankę tekstową, meandryczny wywód, wiodący na manowce rozwidlających się znaczeń, swoisty dys-kurs nieustannie zbaczający z obranego kursu mówienia i myślenia. Kraus stawia świat przed „trybunałem” w postaci instancji w trójcy jedynej: „poeta, sędzia, moralista” (Hatvani 69), przemawiając ex katedra, uderzając w ",ton biblijnego proroka” (Hatvani 62). Dyskurs Jelinek konstytuuje się niejako „poza dobrem i złem”, w odosobnieniu, „na uboczu” (Jelinek 2012d), z dala od "głównych szlaków" języka, którego używanie zawsze oznacza poruszanie się po niepewnym gruncie. Pisarka aktualizuje wieszczoną przez Krausa apokalipsę, tworząc polifoniczne „monologi Kasandry”12, a jednocześnie burząc totalitarne konotacje każdej autorskiej wypowiedzi. Kraus i Jelinek przypominają nam o cenie, jaką musimy pła-

9 „Mit heißem Herzen und Hirne / nah't ich ihr Nacht für Nacht. / Sie war eine dreiste Dirne, / die ich zur Jungfrau gemacht".

10 Na tę oscylację między reakcyjną teorią a rewolucyjną praktyką w pisarstwie Krausa zwraca uwagę Gilbert Carr, analizując modernistyczne zmagania Krausa z nowoczesnością.

11 Odwołuję się do słynnej diagnozy Adorno o Krausie i jego umiejętności dokonywania rozróżnień między przyzwoitością a łajdactwem, mądrością a głupotą, językiem i gazetą (Adorno 281).

12 Por. esej pod takim tytułem (Szczepaniak). 
cić za procesy modernizacyjne, wskazują na bezradność w obliczu wykreowanych przez nas samych katastrof techniki, gospodarki, przyrody. Uświadamiają nam iluzję mówienia własnym językiem, ostrzegają przed niebezpieczeństwem utraty podstawowych ludzkich kompetencji (myślenia, wyobraźni, kreatywności), domagają się intelektualnej głębi, analizy, kontemplacji w obliczu powierzchowności kultury felietonu czy telewizyjnego obrazu. Upominanie się o te wartości w świecie zdominowanym przez szybkość przekazów medialnych, przepływów wiedzy, technologii, pieniędzy, w świecie rosnącej standaryzacji zachowań i eskalacji współzawodnictwa - w agonicznej kulturze pędu, która utraciła „mądrość powolności” (Kundera 25), wciąż pozostaje domeną sztuki. Jak pisze Ève Chiapello: „Nie inaczej niż przed dwustu laty dzieła sztuki charakteryzują się tym, że wyrażają tęsknotę za zaczarowanym i czarującym światem - światem, który nie pozwala sobą dysponować” (Chiapello 51). Wiedeńskie „specjalności lokalne” (wyzysk, korupcja, hipokryzja, bezmyślność, kłamstwo medialne, deprawacja języka) w literackim świecie Krausa i Jelinek uzyskują wymiar uniwersalnych prawideł społecznych - prowincja jest wszechobecna, kiedy satyra jest totalna.

\section{Ludo-żercy}

W eseju Karl Kraus Walter Benjamin zwraca uwagę na organizującą tekst w czasopiśmie „Die Fackel” zasadę przemocy: „Ociekające krwią nowości tej ‘gazety' prowokują wyrok. I to wyrok kierujący się z całą gwałtownością przeciw samej prasie” (Benjamin 1996: 126). Jednocześnie wskazuje na kanibaliczne źródła tego krytycznego gatunku, nazywając satyryka ogólnie "figurą, w której cywilizacja recypowała ludożercę" (Benjamin 1996: 147). Ponadto konkretyzuje to wyobrażenie „ludożerczości”, opisując Krausa jako twórcę tworzącego dla siebie role, „w których chłeptał krew” (Benjamin 1996: 151). Regułę rządzącą „Pochodnią" definiuje sam „pogromca frazesu" (Benjamin 1996: 160) w pierwszym numerze za pomocą słynnej formuły odżegnującej się od wszelkiej łagodności („was wir bringen”), a preferującej modus destrukcji, zniekształcania, zabijania („was wir umbringen” (Kraus 1899: 1)). Czas, w którym przyszło mu żyć niejako „za karę”, charakteryzuje Kraus jako epokę „tak żałosną, że nie miała żadnego pojęcia o swej żałosności, że nie słyszała chichotu" (Kraus 1929: 3). Tworzenie satyry jest w takich warunkach prawdziwym wyzwaniem, bo rzeczywistość niemal przekracza granice pisarskiej fantazji, dlatego Kraus został "artystą cytatów”: "Sztuka retoryczna polega na opuszczaniu cudzysłowu, na plagiatowaniu przydatnych faktów, na stosowaniu chwytów zamieniających wycięty fragment w sztukę" (Kraus 1929: 3).

Poetologię okrucieństwa wykłada także Jelinek, kiedy tłumaczy swoją strategię czytania podobną do polowania drapieżnego ptaka: 
Filozofię na przykład czytam jak drapieżny ptak. Coś przerzuca kartki, za późno orientuję się, że to ja, i nagle z niesłyszalnym krzykiem rzucam się na miejsce, które akurat zauważyłam, wyrywam je, jeszcze ociekające krwią i ohydne, napycham się nim, sok myśli ścieka mi po brodzie, to, co robię, wcale nie wygląda ładnie, a potem od razu szukam dalej [...], czy mogę coś wykorzystać, wbetonować w moje własne pisanie, tak, jak kiedyś wmurowywało się żywe istoty w fundamenty budynków. Żeby budynki dłużej przetrwały, tak mi się przynajmniej wydaje. Nie sądzę, że moje pisanie przetrwa dłużej tylko dlatego, że wryłam w nie kawałek mięsa Heideggera albo Nietzschego, nawet nie ukradkiem, choć je ukradłam, a germaniści niech się potem bawią w szukaj, piesku, szukaj! (Jelinek 2012b: 99).

Pisarka wielokrotnie używała pojęcia „wampiryzmu” jako metafory produkcji tekstu satyrycznego czy ogólniej - systemu cyrkulacji literatury: „To jest strategia wampiryczna. Ale inni autorzy wysysają krew żywych ludzi, ja tego nie robię albo bardzo rzadko, a jeśli już, to przeważnie sama jestem tą wysysaną" (Berka 135).

Kraus i Jelinek. Maszyny językowe. Innożercy. Artyści sekundarni. Pożyteczni barbarzyńcy ${ }^{13}$. Pasożytują na medialnie zapośredniczonej rzeczywistości ${ }^{14}$. Piętnują, a zarazem performatywnie demonstrują przemoc zorganizowaną w języku. Przedstawić znaczy obnażyć, u Jelinek dodatkowo zakłócić, uruchomić plenienie się nowych sensów, narastanie materii tekstowej - jest to strategia „wynajmowania” i „maltretowania” słów, którą pisarka charakteryzuje za pomocą formuły „prze-pisuję i prze-sadzam” („ich übertreibe und ich überschreibe”) (Jelinek 2005: 4). Cytować to uśmiercać przytaczane frazy poprzez ich redukcję, manipulację, nową kontekstualizację, ale także dawać im nowe życie upiorów, fantomów, tworów zdeformowanych:

Widmowe błądzenie słów. Widmowe powracanie nie zdarza się słowom przypadkowo po śmierci, która przydarzyła się jednym lub oszczędziła inne. Widmowe powracanie jest udziałem [partage] wszystkich słów i to już od momentu ich zaistnienia (Derrida 2000: 60).

Ludo-żercy mają trupa w piwnicy, na dnie tekstu rozkłada się inny tekst. „Wchłonięcie cytowanych słów zamienia się w ich pogrzeb” (Fliedl 20). Przytaczane fragmenty obcej mowy są - w podwójnym znaczeniu tego słowa: po-chowane.

Kraus i Jelinek hołdują zasadzie kreacji i destrukcji ${ }^{15}$, czyli negatywnej produktywności w formie cytowania. Anonimizują językowe wypowiedzi, eksponują

13 Nawiązuję do pojęcia Benjamina "das positive Barbarentum”, które koresponduje z użytym w eseju o Krausie pojęciem „Unmensch” (Benjamin 1991: 216).

14 „Przyszywam się do rzeczywistości, która jest mi oferowana jako amalgamat, jako oczyszczona, jako przefiltrowana przez różne opinie [...]. Jestem pasożytem rzeczywistości [...]" (Jelinek 2011).

15 W odniesieniu do Krausa por. Norberg. 
(medialną) redukcję języka do arbitralnej frazy, wskazują granice indywidualnego mówienia (Vogel 48). Przekonują, że nie potrafimy opanować języka, możemy jedynie zbliżać się do jego tajemnic i pułapek. Kraus konstytuuje figury dramatyczne w postaci "masek i lemurów”, dokument jest postacią, felieton otrzymuje usta, frazy poruszają się na „dwóch nogach” (Kraus 1991) ${ }^{16}$. Jelinek proponuje wysyłać na scenę ubrania bez aktorskich ciał i przekonuje: „Aktorzy nie mówią, oni SĄ mówieniem" (Jelinek 2012f: 114). Oprócz kondycji habitus cannibalis, inscenizacji cytatów wyrwanych z kontekstów, montażu i kolażu, budowania nowych skojarzeń obydwoje $\mathrm{w}$ różnym stopniu prowadzą ostre polemiki ad personam lub $\mathrm{z}$ anonimowymi konsumentami medialnej „papy”. Panowanie „czarnej magii” (Kraus 1989) drukowanych liter felietonu w epoce Krausa, niepohamowana ekspansja obrazów w epoce Jelinek niweczą intelektualną głębię, redukują wieloznaczność, deprawują dyskurs publiczny. Jednak jak spekuluje Yasmin Hoffmann, w obliczu „fatalnych strategii” (Baudrillard) współczesnych mediów Krausowi „po prostu odebrałoby mowę" (Hoffmann 41).

\section{Dobro-czyńcy}

W grudniu 1917 roku Róża Luxemburg napisała list z wrocławskiego więzienia do żony Karola Liebknechta, Sophie, w którym opowiada o „wielkiej przykrości”, jakiej była świadkiem, obserwując więzienny dziedziniec. Wjechały tam wozy zaprzężone $\mathrm{w}$ bawoły stanowiące zdobycz wojenną $\mathrm{z}$ Rumunii, za pomocą batów zmuszane do ciągnięcia ciężarów, otrzymujące marne pożywienie. Jeden z żołnierzy "gwałtownie począł okładać je grubem biczyskiem", aż oburzona dozorczyni zarzuciła mu brak litości nad zwierzętami, na co żołdak odparł, że nad żołnierzami też nikt nie ma miłosierdzia, „i jeszcze mocniej uderzył” (Listy 53). Widząc krew na skórze jednego z bawołów - zwierzęcia o łagodnych oczach, wyglądającego jak płaczące dziecko, które nie rozumie, za co spotyka je kara - więźniarka komentuje: „Sonieczko! Skóra bawołów jest przysłowiowo twarda i wytrzymała, a jednak była rozdarta" (Listy 53). Solidarność i współczucie dla katowanej istoty manifestuje się w następujących słowach: „Nagle zwierzę spojrzało na mnie, a z oczu jego łzy spływały, jego własne łzy. Najmilszemu bratu nie można było bardziej boleśnie współczuć, jak ja w mojej niemocy współczułam temu cichemu bólowi" (Listy 54). Róża Luxemburg nazywa „, biedne bawoły” swoimi najmilszymi braćmi oraz jednoczy się $\mathrm{z}$ nimi w bólu, cierpieniu, bezsilności, tęsknocie do wolności. $\mathrm{W}$ innym liście stara się argumentować bardziej racjonalnie, stwierdzając, że przecież nie może „płakać nad każdym obitym bawołem" (Listy 65), jednak jej wrażliwość okazuje się silniej- 
sza: „I tak w swej celi ze wszech stron jestem cienkiemi i bezpośredniemi połączona nićmi z tysiącem małych i większych stworzeń" (Listy 65).

W 1920 roku Karl Kraus wydrukował w „Pochodni” list Róży Luxemburg jako nadający się do podręczników szkolnych przykład postawy humanitarnej. Otrzymał odpowiedź jednej z anonimowych czy telniczek z Innsbrucka (zidentyfikowanej jako hrabina Ida von Lill-Rastern von Lilienbach), która dała wyraz swemu oburzeniu oraz brutalnie zakpiła z Róży Luxemburg, zarzucając jej demagogię i proponując, by zatrudniła się jako „strażniczka w ogrodzie zoologicznym” (tam nie zetknęłaby się z kolbami karabinów) albo żeby wyjaśniała bawołom istotę rewolucji, a nawet założyła republikę bawołów. Retoryka listu wychowanej w węgierskim majątku ziemskim hrabiny, zapewniającej o doskonałej znajomości świata zwierzęcego, szczególnie gatunku bawołów, jest niemal militarystyczna, pełna pogardy wobec poniżanych zwierząt oraz „histerycznych” kobiet pokroju Róży Luxemburg (pośrednio także wobec Krausa). Hrabina podziwia "naszych dzielnych żołnierzy” („unsere Feldgrauen”) toczących ciężkie walki w Rumunii, uważa za oczywiste, że bawoły pełnią funkcję zwierząt pociągowych, aprobuje używanie wobec nich przemocy, podobnie jak wobec dzieci, którym wymierzony policzek rzekomo nigdy nie zaszkodzi. Krytyka „wichrzycielki” Róży Luxemburg zwieńczona jest moralizatorską pointą o charakterze mentorskiego pouczenia adresowanego do kobiet, które nie rozumieją swojego przeznaczenia: „O wiele bardziej niż sentymentalności i podżegania, potrzebujemy skromności, pracy w najbliższym otoczeniu, łagodności i dobroci" (Kraus 1920: 5).

Kraus nie tylko wydrukował list hrabiny w „Pochodni”, lecz także, nie przebierając w środkach językowego wyrazu, zredagował komentarz i zatytułował całość Antwort an Rosa Luxemburg von einer Unsentimentalen (Odpowiedź kobiety pozbawionej uczuć na list Róży Luksemburg). Eseista nie waha się używać wobec hrabiny określeń obraźliwych typu „bestia” (Bestie) czy „hetera“ (Megäre), proponuje udostępnić jej list młodzieży w celach edukacyjnych, aby poznała także „nikczemność” ludzkiej natury, szczególnie w wydaniu niemieckich „reproduktorek” (Fortpflanzerinnen), które ewidentnie zawarły pakt $\mathrm{z}$ diabłem ${ }^{17}$ i usiłują "obrzydzić" życie, wskazując na perspektywę tego, czemu w swym „zaczadzeniu ideałem bohaterskiej śmierci" (Heldentodgeilheit) nie potrafiły zapobiec w 1914 roku (Kraus 1920: 5). Językowa furia obrońcy Róży Luksemburg, skierowana przeciwko „nieludzkiemu wylęgowi właścicieli ziemskich dóbr i szlachetnej krwi" (entmenschte Brut von Guts- und Blutbesitzern), obejmuje nie tylko dyskredytacje pochodzenia, poziomu umysłowego, inteligencji emocjonalnej autorki impertynenckiego listu, lecz także prowadzi do uogólnień i wynosi argumentację na duchowo-moralną płaszczyznę trybunału zdolnego do bezpardonowego osądzania bestialstwa za pomocą słowa.

17 W tym miejscu można wskazać na pewien aforystyczny suplement, mianowicie: „Diabeł jest optymistą, o ile sądzi, że może ludzi uczynić gorszymi" (Kraus 1975: 32). 
Hrabina wychwalająca żołnierzy zostaje zatem skazana na porzucenie szlachectwa i sprzątanie toalet $\mathrm{w}$ wojskowych koszarach - to jej należą się baty. Scena poniżania zwierząt reprezentuje niewolnictwo ludzi, które nie zniknie, dopóki bestialskie „walkirie" z Niemiec czy Węgier nie przestaną podziwiać militarnej tresury bezbronnych zwierząt i czynić przedmiotem aroganckich żartów tych, którzy nazywają zwierzęta braćmi.

W 2009 roku Jelinek opublikowała esej Die brennende Hosenhaut (Płonąca materia spodni), w którym opisuje zdarzenie z 30 maja: ubiegający się w Austrii o azyl młody Pakistańczyk podpalił się na dworcu Welser Bahnhof w akcie rozpaczy i protestu przeciwko trudnej sytuacji materialnej i egzystencjalnej (konieczność utrzymania się ze 180 euro pomocy państwowej). Autorka przy tacza dosłownie medialne reakcje na ten wypadek, szczególnie anonimowe posty świadczące o braku współczucia, nienawiści, ksenofobii - głosy komentujące w sposób „niepozostawiający wątpliwości, ale pozostawiający mdłości” („,in der bewehrten Art, nein, kein Tippfehler" (Jelinek 2009)), np. „Macie w ogóle pojęcie, ile jest bezdomnych w samym Wiedniu???” albo „Mógł pojechać do domu. Za te 180 euro dostanie bilet do granicy pakistańskiej, a dalej pieszo". Pojawiają się wprawdzie także inne głosy, , "ale w chórze nie słychać ich zbyt dobrze", dominuje bowiem "grzmiący ton nagonki", skierowany nie tylko przeciwko azylantom, lecz także przeciwko ich obrońcom - dobro-czyńcom (Gutmenschen ${ }^{18}$ ), którzy w ostatnim czasie (ta diagnoza jest obecnie znowu aktualna) stali się przedmiotem intensywnych ataków. Sednem argumentacji Jelinek jest fakt, że w epoce postprawdy Gutmensch ${ }^{19}$ jest określeniem obelżywym, zatem ci, którzy reprezentują humanizm, w świadomości opinii publicznej uchodzą za nieludzkich.

Natomiast nowe typy humanitarne głoszą apoteozę brutalności. I czują się przy tym świetnie. [...] Dla nich niezaprzeczalne jest to, że dobro-czyńcy to śmieci, że stawiając zgubne żądania, przynoszą społeczności, od której zbyt wiele wymagają, jedynie szkodę (Jelinek 2009).

18 Określenie Gutmensch, które można przetłumaczyć jako „idealista” (choć to nie do końca oddaje jego znaczenie i emocjonalne zabarwienie) pochodzi z czasu rewolty 1968. Słowo to weszło do powszechnego użycia w latach dziewięćdziesiątych XX wieku i stało się negatywnie nacechowanym określeniem osób zaangażowanych, szczególnie zwolenników poprawności politycznej (zob. Bittermann). W Austrii używano go w celu zniesławienia artystów zaangażowanych, sprzeciwiających się ksenofobicznej, antysemickiej, rasistowskiej polityce skrajnie prawicowej partii FPÖ, w tym Jelinek, która była atakowana przez Jörga Haidera. W kontekście aktualnego kryzysu imigranckiego słowo Gutmensch ponownie pojawia się w debacie publicznej. W Niemczech zostało ono ogłoszone "antysłowem roku” 2015.

19 Jelinek odnosi się do kontekstów politycznych; mówiąc o przeciwnikach dobro-czyńców, ma na myśli austriackiego prekursora prawicowego populizmu Jörga Haidera, a czytelnicy i czytelniczki eseju powinni mieć świadomość, że autorka samą siebie sytuuje wśród atakowanych dobro-czyńców (Gutmenschen). 
Elfriede Jelinek odnosi się do językowej kreacji świata odwróconego, w którym ludzi czyniących dobro nazywa się złymi. „Dobro-czyńca jest niczym innym, jak dobrem, które czyni lub czynić zamierza. Nie jest niczym więcej. Jest więc niczym. Przede wszystkim zaś: Nie myśli" (Jelinek 2009). Bezosobowemu głosowi eseistycznemu, który niekiedy przyjmuje formę „ja”, przeciwstawione jest ekspandujące, chóralne, zadufane w sobie "my” - złowrogi sound większości zawsze „najpierw myślącej” przeciw obcokrajowcom oraz ich dobro-czyńcom. „My znowu jesteśmy kimś. Kim my jesteśmy? Jesteśmy tym, kim jesteśmy" (Jelinek 2009). Wkradając się w system atakowanego dyskursu Jelinek niejako utrzymuje przy życiu konstelację świata postawionego na głowie, przypisując intelektualizm tym, którzy systematycznie zwalczają wroga opatrzonego etykietą Gutmensch.

Jeżeli ktoś myśli, to przecież nie może być dobro-czyńcą. Dobrze, myśli więc sobie. Kto dobry, ten nie myśli. Wystarczy, że dobry. Ten, kto przeciwny jest dobro-czyńcom - to jest myśliciel, nie ma innej możliwości, bo dobro-czyńca nie myśli, myśli tylko ten nowy myśliciel, powiem więcej, on myśli po nowemu, to tylko tak staro wygląda, co on myśli, tak naprawdę to jest całkiem nowe. Jeśli to już kiedyś raz było, co on myśli, to to się całkiem odnowiło, nowe jest. On nic innego nie potrafi, ten wróg dobro-czyńców, myślenie stało się jego drugą naturą, widać to wtedy, kiedy domaga się zróżnicowania, no bo przecież nie wpuścimy wszystkich, co to by się tutaj działo! Tego chcą inni, my tego nie chcemy. My musimy różnicować, kto jest nam potrzebny, a kto nie, nie przyjmiemy wszystkich, jak chcą tego ci lewaccy dobro-czyńcy (Jelinek 2009).

Sarkastyczny wywód eseistyczny sugeruje zupełny brak wyrozumiałości wobec ofiary oraz pogardę dla jej politycznie poprawnych obrońców, nazywanych dobrymi, choć sami się tak nie określają („nawet na to są za głupi, no bo nie myślą”). Tylko współczują, lamentują, namawiają do marszów solidarności, do darowizn, do gestów pomocy, ale obca im jest „prawda myślenia”. Dlatego należy wreszcie skończyć z tą "dobro-czynnością", a wynik kolejnych wyborów pokaże wyraźną przewagę mówiącego "my”: "potem przyjdą ci, co podnoszą krzyż, aby wygnać wszystkich innych w jego imieniu, Abendland in Christenhand" (Jelinek 2009). Zachodnia „krucjata myślicieli" przyniesie pożądany efekt homogenicznej wspólnoty, która widzi tylko samą siebie i samą siebie rozumie - wystarczy jej życie doczesne, a na ",tamten świat" mogą pójść ci dobrzy, ,jak im się tam aż tak bardzo podoba, oni w ogóle nie są z tego świata" (Jelinek 2009).

Satyryczna erupcja językowa w sposób pozornie nieumotywowany zamienia się w monolog podmiotu, który zdaje relację z lektury listu Róży Luxemburg do Sophie Liebknecht o brutalnych żołdakach katujących zwierzęta ${ }^{20}$, następnie z lek-

20 Wspólne dla Krausa i Jelinek jest wywiedzione w referowanym tutaj medialnym dyskursie (listy Luxemburg, eseje w „Die Fackel” i na stronie www.elfriedejelinek.com) przywiązanie do zwierząt, 
tury odpowiedzi hrabiny von Lill-Rastern i wreszcie z lektury ,,jednego z najostrzejszych i najbardziej gorzkich esejów" Krausa, który „wymachuje biczem” języka jako prekursor współczesnej dobro-czynności („Gutmensch einer vergangenen Zeit”) z czasów, gdy „jeszcze nie wymyślono myślenia” (Jelinek 2009).

To już jednak przeminęło i nie wróci. Dzisiaj nikt już nie wie, co to jest człowiek, odkąd istnieje ten dobro-czyńca (Gutmensch), odkąd go wynaleziono, a potem zniesiono. O takich jak on nie musicie się już martwić! Jego formy zostały spalone, stopiły się jak nogi tego pakistańskiego azylanta, który się podpalił, bo nie może tutaj żyć. Ale czy tutaj da się w ogóle żyć? (Jelinek 2009).

Jelinek i Kraus - mistrzowie satyry jako sztuki dysonansu - przypisują języko$\mathrm{wi}^{21}$ funkcję strategiczną dla aktywności intelektualnej, etycznej, estetycznej, ale jednocześnie problematyzują zasadę oryginalności w sensie posługiwania się mową „wynajętą" oraz zacierania granic między językiem a jego krytyczną analizą. Jelinek interesuje się nie tylko tekstem, lecz także jego recepcją, co powoduje efekt palimpsestowy: nawarstwianie się tekstu oraz częsta zmiana perspektywy komplikują lekturę, w prowadzają hermeneutyczną niepewność, zakłócają poczucie komfortu²2. Jednak także komunikacja Krausa z czytelnikami i czytelniczkami nie przebiega zbyt gładko, o czym informuje następujący aforyzm: „Ja i moja publiczność rozumiemy się doskonale: ona nie słucha tego, co ja mówię, a ja nie mówię tego, co ona chciałaby słyszeć" (Kraus 1975: 26).

Krytycznych artystów łączy polemiczna produktywność sekundarna, z której wynika reżim intertekstualności obejmujący swym zasięgiem teksty medialne o krótkiej żywotności. Oznacza to z jednej strony przebudowę kanonu, z drugiej narażenie również własnych, osadzonych głęboko w lokalnych kontekstach utworów na mechanizmy erozji i dezaktualizacji. Implikacją takiej estetyki są ciągi skojarzeniowe, pozwalające na uogólnienia i abstrakcje, na przykład zrównanie świata ludzi i zwierząt czy wpisanie austriackiego azylanta w historię lewicowej tradycji mieszczańsko-proletariackiej. Paradoksalnie satyra staje się w pewnym sensie nosicielką utopii, narzędziem dobroczynności, modusem naprawy świata - satyra jest

opowiadanie się po stronie żywych istot, krzywdzonych przez ludzi. Jelinek wielokrotnie mówiła o zwierzętach jako istotach, które nie ranią się nawzajem tak jak ludzie; Kraus porównuje w eseju węgierską hrabinę do gęsi biegających po podwórzu jej majątku ziemskiego (gęś nie byłaby tak bezczelna, by napisać podobny list).

21 Język jest u obu autorów zarówno przedmiotem, jak i podmiotem, różne jest natomiast podejście do kwestii świadomości językowej i możliwości dotarcia do oryginału ukrytego w „strategiach uwodzenia" (por. Baudrillard).

22 Czytelnicy i czytelniczki tekstów Jelinek konfrontowani są z koniecznością utraty swej hermeneutycznej niewinności - jest ona wręcz przesłanką rozumienia jej tekstów, które ponadto wymaga czytania intertekstualnego, w przeciwnym razie lektura może prowadzić do diagnozy tekstowego non-sensu. 
progresywna. Kraus przekonuje: „Satyrze obca jest wszelka wrogość, oznacza ona życzliwość (Wohlwollen)23 dla idealnej wspólnoty, do której dociera się poprzez realne indywidua, nie przeciw nim" (Kraus 2013: 162).

\section{Wszech-człowiek i nie-kobieta}

Nawiązując do początkowych rozważań na temat męskiego panteonu austriackich satyryków, chciałabym na koniec zadać pytanie, czy satyra ma płeće ${ }^{24}$. Benjamin rozpatruje polemiczną osobowość Krausa w kategoriach „wszechczłowiek, demon, nieczłowiek", wskazując w pierwszej części analizy na ucieleśnianą przez wiedeńskiego pisarza "tajemnicę autorytetu”: "Autorytet nigdy nie kończy się inaczej: umiera albo rozczarowuje" (Benjamin 1996: 134), w drugiej na jego próżność, gest samouwielbienia, „,sztukę samoekspresji” (Benjamin 1996: 137), a w trzeciej opisuje satyryka jako "twór z dziecka i ludożercy” (to "nieczłowiek”, ,nowy anioł”, prototyp prawdziwego humanizmu (Benjamin 1996: 161)) $)^{25}$. Kategoria wszechczłowieka jest wybitnie męska (człowiek = mężczyzna), wszechogarniająca, faustowska ${ }^{26}$. Podstawę techniki cytowania w wydaniu Krausa stanowią przemoc i mesjanizm. Wyrywaniu cytatów z kontekstu towarzyszy ambicja ratowania słowa, uwolnienia go z sieci korupcji, przywrócenia mu statusu „przedpotopowego”. Jeżeli profil idealistycznego światopoglądu Krausa wyznaczają pojęcia: intelekt (Geist), wyobraźnia (Phantasie), natura (Natur), praźródło (Ursprung) (por. Bodin), to Jelinek podziela tylko dwa pierwsze. Diagnoza upadku ludzkości wraz z zanikiem władzy myślenia, duchowości, intelektualizmu, zdolności imaginacyjnych wydaje się niezwykle aktualna w kulturze współczesnej. Jednak z perspektywy Jelinek nie implikuje ona utopijnych wizji powrotu do początku, praźródła, nieskażonej natury, czystości języka, pomimo że noblistka przygląda się nieporównywalnie bardziej zaawansowanej dewastacji świata, ekspansji sztuczności, medialnych technik ogłupiania niż Karl Kraus ${ }^{27}$.

23 W innym miejscu Kraus podkreśla „Nie jestem niczyim wrogiem, jestem życzliwością” (Kraus 2016: 31).

$24 \mathrm{~Np}$. Christiane Künzel formułuje diagnozę twierdzącą i używa sformułowania „das Geschlecht der Satire" (por. Künzel).

25 To trzecie oblicze satyryka jest Benjaminowi najbliższe, określa bowiem „zbawienną" destrukcję, m.in. poprzez śmiech wywołujący efekt niesamowitego, a tym samym oczyszczający. Na temat paradoksalnej triady „Allmensch" - „Dämon“ - „Unmensch“ zob. Peiter 98-112.

26 Benjamin E. Sax analizuje obraz Krausa w eseju Benjamina jako nowoczesnego żydowskiego Fausta, rozpatrując wspomnianą triadę analitycznych pojęć w kategoriach: teza - antyteza - synteza. Unmensch jawi się jako „prototyp prawdziwego humanizmu, niepodobnego do klasycznego oświeceniowego" (Sax: 5).

27 Nasuwa się parafraza słynnego dyktum Krausa „zu Hitler fällt mir nichts ein” (na temat Hitlera nie mam nic do powiedzenia), otwierające Die dritte Walpurgisnacht (1933) w postaci „Zur künstlichen Intelligenz fällt mir nichts ein" (Na temat sztucznej inteligencji nie mam nic do powiedzenia). 
Jelinek jest pisarką dekonstrukcji, różnicy, powtórzenia, eksponentką zasady wieloznaczności, heterogeniczności, depolaryzacji myślenia - jest pisarką différance. Jej twórczość można interpretować jako pożegnanie ze światem dualistycznych podziałów, binarnych opozycji, wyraźnych granic, jako protest przeciwko uniwersalnemu centrum (logos, Bóg, ojciec, autorytet artysty). Jest artystką przemijalności, znaczenia śladów w sensie wyłożonym przez Jacquesa Derridę:

Ślad stanowi wymazanie siebie, własnej obecności, ustanawia go groźba lub obawa jego nieodwołalnego zniknięcia, zniknięcia swego znikania. Ślad nie do wymazania nie stanowi śladu - to jakaś pełna obecność, jakaś nieruchoma i niezniszczalna substancja, jakiś Syn Boży, znak paruzji, a nie siewu czy śmiertelnego ziarna (Derrida 2004: 400).

Specyficznej (męskiej) manii wielkości w wydaniu „boskiego” Krausa ${ }^{28}$ „upiorna" Jelinek przeciwstawia własną oryginalną koncepcję autorstwa: autoironiczny gest samoumniejszania, strategię pojawiania się i znikania, emancy pację dwuznaczności, podważanie kategorii rzekomo ugruntowanych, wzbranianie się przed tworzeniem nowej, niezachwianej wiedzy, formułowaniem prawd objawionych: „Nie jestem władcza (herrisch), bo nie jestem władczynią (Herrin), przepraszam, nie jestem władcą (Herr). Na to sobie pozwalam" (Jelinek 2013b).

Kraus reprezentuje ową „pełną obecność”, „niezniszczalną substancję”, ,paruzję", boskie słowo starotestamentowego proroka, apodyktyczność duchowego arystokraty, ale także ambiwalencje urodzonego satyryka (Johnston 230$)^{29}$, który jednak posiada władzę nad cytatami, identyfikuje się ze swoim językiem, wyczerpuje możliwości polemiczne „aż do dna” (Benjamin 1996: 139). Jelinek zwalcza fikcję substancji, kwestionuje pozycję autorytetu, odrzuca dyskurs pewności siebie, destabilizuje tożsamość, artykułuje słabość i bez-silność, tworzy dialektyczne napięcie między imperatywem a niemożnością mówienia i pisania, szczególnie jako kobieta w kulturze, która pozbawia artystki suwerennego "głosu":

Okropny strach ogarnia mnie na myśl o tym, że ktoś mnie słucha choć trochę tak, jakbym była jakimś bogiem. Jak już wspomniałam, teraz zdecydowanie odrzucam wszelkie oddziaływanie mojego pisma. Na szczęście i tak za bardzo nie działa. Nie chcę być tak skuteczna jak pismo proroka, którego może zrozumieć każdy, kto chce (Jelinek 2012g: 69).

Pomimo przekonania, że ,język, precyzyjny literacki język, nie może konkurować już z tym niebezpiecznym, pewnym siebie, nieznającym zwątpienia językiem

28 Juliane Vogel pisze o władzy Krausa, polegającej na dyskredytującym cytowaniu, ale także na „interwencjach wyposażonego w boskie uprawnienia sędziego-redaktora" (Vogel 49).

29 Radykalizm i jednostronność Krausa w ocenie Johnstona nie pozwalają mu na obiektywną charakterystykę istoty austriackości, dlatego dorobek wiedeńskiego satyryka nie został uwzględniony w monografii na temat mentalności austriackiej. 
szykownych technokratów i twardzieli, którzy zalewają nas teraz ze wszystkich stron" (Jelinek 2012c: 58), Jelinek nie tylko nie przestaje pisać, lecz także - paradoksalnie - opatruje swoje pismo sygnaturą auktorialną, podkreślając status autorki-kobiety i demonstrując w kaskadach cytatów, jak zatraca się fikcja suwerennego autorstwa, obecności, autorytetu.

Kraus myśli w kategoriach hierarchicznych, Jelinek w kategoriach emancypacyjno-równościowych. On mówi głosem „fallicznym”, ona "heterogenicznym”. On czytał Ottona Weiningera, ona - Judith Butler. Kraus był zakładnikiem polaryzacji płci oraz typowych dla tamtych czasów męskich fantazji. Mitologizował kobiecą seksualność, odmawiał kobietom atrybutów intelektualnych, udziału w życiu publicznym, aktywności twórczych, słowem: przypisywał im zasadę coito ergo sum $^{30}$. W jego mizoginicznym $\mathrm{w}$ gruncie rzeczy uniwersum ${ }^{31}$ wyobrażenie artystki, intelektualistki, feministki (dzisiaj Jelinek) oznacza fatalną pomyłkę natury, nosi znamiona horroru („Sztuka kobieca: im lepsze wiersze, tym lica szpetniejsze” (Kraus 1986: 31) ${ }^{32}$ ). Powinowactwo konstatowanej przez Jelinek artystycznej i intelektualnej wspólnoty dobro-czynności być może skomentowałby tak: „Dobroczynne kobiety to często takie, którym nie dane już jest czynić dobrze" (Kraus 1975: 52). Przytoczony aforyzm należy jednak interpretować wraz z immanentnym "zapachem kontekstu" (Bachtin), czyli całym balastem znaczeń, wizji, fantazmatów na temat kobiecości, które konstytuowały mizoginiczną epokę kryzysu męskości na przełomie wieków XIX i XX, kształtując także horyzont myślowy Krausa. Wkroczenie Jelinek w obszar męskiej domeny duchowości, filozofii, sztuki z perspektywy tamtej epoki nosi znamiona „fallicznej” uzurpacji. I właśnie wykluczenie kobiecości ze sfery publicznej, problem marginalizowanej w kulturze kobiety myślącej, tworzącej, piszącej, artystki jako istoty sekundarnej to wielki temat Jelinek, który pisarka traktuje $\mathrm{z}$ typową dla siebie satyryczną swadą. Zdaje się ironicznie cytować i potwierdzać anty-kobiecy patos mizoginów sprzed stu lat, kiedy pisze o sobie „zmaskulinizowana staruszka" (,die vermännlichte Alte” (Jelinek 2014)). W świetle retoryki aforyzmów Krausa na temat kobiecości interesująca wydaje się ponadto następująca konstatacja pisarki, niejednokrotnie charakteryzowanej jako „agresywna” czy „niekobieca":

Gdy tylko [...] twórczość jakiejś kobiety staje się agresywna czy oskarżycielska, tak jak moja, to taką autorkę natychmiast ogłasza się heterą (Megäre), podczłowiekiem (Unper-

30 „Paralelizm dowcipu i erotyki... Kobieta koituje genialnie... Dama kogituje genitalnie” (Kraus 1975: 52).

31 Sformułowanie "w gruncie rzeczy" jest w pewnym sensie uprawnione, bo jednym z postulatów współczesnego feminizmu jest prawo kobiet do realizacji własnego pożądania (Weiningera i Krausa można zatem w tym aspekcie uznać za prekursorów). Zob. na ten temat: Wojnicka.

32 „Frauenkunst: Je besser das Gedicht, desto schlechter das Gesicht”. 
son) i zaczyna snuć wobec niej fantazje wymazywania (Auslöschungsphantasien) (Winter 15).

Kanonizacja w postaci literackiej Nagrody Nobla oraz międzynarodowego uznania, jakiej dostąpiła Jelinek, pozwala mieć nadzieję, że recepcja twórczości dwojga czołowych austriackich ludo-żerców dobro-czyńców, satyryków jako ostatnich obrońców humanizmu, za sto lat pozwoli docenić ich zasługi w demonstrowaniu nieusuwalnej wtórności słowa i że nie będzie rządziła się zasadą genderingu satyry, która przesądzi o tym, że Kraus ze swym organem walczącym (Die Fackel) to był jakkolwiek pojęty „dobry człowiek” z Wiednia (guter Mensch, człowiek = mężczyzna), zaś Jelinek ze swoją wampiryczną estetyką - to „zła kobieta była” (böse Frau) ${ }^{33}$.

\section{BIBLIOGRAFIA}

Adorno, Theodor W. "Juvenals Irrtum”. Minima Moralia. Reflexionen aus dem beschädigten Leben. Frankfurt a. M.: Suhrkamp, 1982. S. 280-283.

Bachmann, Ingeborg. „Rede zur Verleihung des Anton-Wildgans-Preises“. Essays, Reden, Vermischte Schriften, Anhang. Red. Ch. Koschel, I. von Weidenbaum, C. Münster. München-Zürich: Piper, 1993. S. 294-297.

Baudrillard, Jean. O uwodzeniu. Przeł. Janusz Margański. Warszawa 2005.

Benay Jeanne, Stieg Gerald, red. Österreich (1945-2000). Das Land der Satire. Berlin-Wien: Peter Lang, 2002.

Benjamin, Walter. „Erfahrung und Armut”. Gesammelte Schriften II. Frankfurt a. M.: Suhrkamp, 1991. S. 213-219.

Benjamin, Walter. „Karl Kraus”. Przeł. Krystyna Krzemieniowa. Anioł historii. Eseje, szkice, fragmenty.

Wybór i opracowanie H. Orłowski. Poznań: Wydawnictwo Poznańskie, 1996. S. 125-161.

Berka, Sigrid. Rozmowa z Elfriede Jelinek. Modern Austrian Literature 2 (1993). S. 127-155.

Bittermann, Klaus, red. Das Wörterbuch des Gutmenschen. Betroffenheitsjargon und Gesinnungskitsch. München: Piper 1998.

Bodin, Jay F. „Karl Kraus's conception of language”. Modern Austrian Literature 1/2 (1975). S. 269-314.

Burger, Rudolf. „Der böse Blick der Elfriede Jelinek”. Gegen den schönen Schein. Texte zu Elfriede Jelinek.

Red. Ch. Gürtler. Frankfurt a. M.: Neue Kritik, 1990. S. 17-29.

33 Posługując się identyfikowalnym w kontekście polskim słynnym cytatem filmowym, nawiązuję jednocześnie do recepcji tekstów Jelinek, która szczególnie w Polsce w dużej mierze sprowadzała i wciąż jeszcze nierzadko sprowadza się do interpretacji biografistycznych oraz przypisywania autorce „złego spojrzenia” czy nieuprawnionego (bo kobiecego) satyrycznego gestu agresji, a także do estetyki chłodu bezrefleksyjnie przenoszonej na osobę pisarki.

Dziękuję Austriackiemu Forum Kultury (w szczególności dr Agnieszce Borkiewicz) oraz prof. Adamowi Lipszycowi za sprowokowanie mnie do zajęcia się tematem „ludożerców w kulturze". 
Carr, Gilbert. „Figures of repetition: Continuity and discontinuity in Karl Kraus's Satire”. Modern Language Review 102 (2007). S. 68-80.

Chiapello, Ève. „Evolution und Kooption. Die 'Künstlerkritik' und der normative Wandel”. Kreation und Depression. Freiheit im gegenwärtigen Kapitalismus. Red. Ch. Menke, J. Rebentisch. Berlin: Kadmos, 2010. S. 38-51.

Derrida, Jacques. „Freud i scena pisma”. Pismo i różnica. Przeł. Krzysztof Kłosiński. Warszawa: Wydawnictwo KR, 2004. S. 347-402.

Derrida, Jacques. Szibbolet dla Paula Celana. Przeł. Adam Dziadek. Bytom: FA-art, 2000.

Eisenreich. Herbert. „Das schöpferische Misstrauen oder Ist Österreichs Literatur eine österreichische Literatur?". Das große Erbe. Aufsätze zur österreichischen Literatur von Otto Basil, Herbert Eisenreich, Ivar Ivask. Graz-Wien: Stiasny, 1962. S. 94-126.

Fliedl, Konstanze. „Im Abseits. Elfriede Jelineks Nobelpreisrede”. Elfriede Jelinek. Sprache, Geschlecht und Herrschaft. Red. F. Rétif, J. Sonnleitner. Würzburg: Königshausen \& Neumann, 2008. S. 19-31.

Hatvani, Paul. „Karl Kraus und die totale Satire”. Modern Austrian Literature 1/2 (1975). S. 61-102.

Hoffmann, Yasmin. „'Hier lacht sich die Sprache selbst aus'. Sprachsatire - Sprachspiele bei Elfriede Jelinek". Dossier 2: Elfriede Jelinek. Red. K. Bartsch, G.A. Höfler. Graz-Wien: Droschl, 1991. S. 41-55.

Hofmeister, Donna. „Access Routes into Postmodernism: Interviews with Innerhofer, Jelinek, Rosei, and Wolfgruber". Modern Austrian Literature 2 (1987). S. 97-130.

Jelinek, Elfriede. „Austria. Niemiecka bajka. Mowa z okazji otrzymania Nagrody im Heinricha Heinego". Przeł. Lucyna Wille. Moja sztuka protestu. Eseje i przemówienia. Red. A. Jezierska, M. Szczepaniak. Warszawa: W.A.B., 2012a. S. 281-305.

Jelinek, Elfriede. „Czytanie”. Przeł. Elżbieta Kalinowska. Moja sztuka protestu. Eseje i przemówienia. Red. A. Jezierska, M. Szczepaniak. Warszawa: W.A.B., 2012b. S. 98-100.

Jelinek, Elfriede. „Die Welt, an der ich schreibe, Mist, wo ist die jetzt wieder hin, vorhin hab ich sie doch schon angefangen“. Der Hammer. Die Zeitung der Alten Schmiede 7, 5 (2005). S. 3-4.

Jelinek, Elfriede. „Moja sztuka protestu”. Przeł. Artur Pełka. Moja sztuka protestu. Eseje i przemówienia. Red. A. Jezierska, M. Szczepaniak. Warszawa: W.A.B., 2012c. S. 58-59.

Jelinek, Elfriede. „Na uboczu. Mowa z okazji otrzymania Literackiej Nagrody Nobla”. Przeł. Monika Szczepaniak. Moja sztuka protestu. Eseje i przemówienia. Red. A. Jezierska, M. Szczepaniak. Warszawa: W.A.B., 2012d. S. 82-97.

Jelinek, Elfriede. „O graniu siebie za pomocą języka. Johann Nestroy”. Przeł. Marek Cieszkowski. Moja sztuka protestu. Eseje i przemówienia. Red. A. Jezierska, M. Szczepaniak. Warszawa: W.A.B., 2012e. S. 182.

Jelinek, Elfriede. „Sens nieważny. Ciało zbędne”. Przeł. Karolina Bikont. Moja sztuka protestu. Eseje i przemówienia. Red. A. Jezierska, M. Szczepaniak. Warszawa: W.A.B., 2012f. S. 112-118.

Jelinek, Elfriede. „Słowo przebrane za ciało. Mowa z okazji otrzymania Nagrody im. Lessinga”. Przeł. Lucyna Wille. Moja sztuka protestu. Eseje i przemówienia. Red. A. Jezierska, M. Szczepaniak. Warszawa: W.A.B., 2012g. S. 65-81.

Jelinek, Elfriede. Babel. Podróż zimowa. Przeł. Karolina Bikont. Warszawa: ADiT, $2013 a$.

Jelinek, Elfriede. Das Parasitärdrama. 2011. Web. 1.05.2017. <www.elfriedejelinek.com>

Jelinek, Elfriede. Die brennende Hosenhaut. 2009. Web.1.05.2017. <www.elfriedejelinek.com> 
Jelinek, Elfriede. Im Wettbewerb. 2010. Web. 1.05.2017. <www.elfriedejelinek.com> Jelinek, Elfriede. Textflächen. 2013b. Web. 1.05.2017. <www.elfriedejelinek.com> Jelinek, Elfriede: „Ich schlage sozusagen mit der Axt drein”. TheaterZeitSchrift 7 (1984). S. 14-16. Johnston, William M. Der österreichische Mensch. Kulturgeschichte der Eigenart Österreichs. Wien-KölnGraz: Böhlau, 2010.

Kraus, Karl. „Der Vogel, der sein eigenes Nest beschmutzt“. Die Fackel $791-786$ (1928). S. 1-5.

Kraus, Karl. „Die Fackel. Vorwort“. Die Fackel 1 (1899). S.1-3.

Kraus, Karl. „Im dreißigsten Kriegsjahr“. Die Fackel 800-805 (1929). S. 3-26.

Kraus, Karl. „Nestroy und die Nachwelt”. Die Fackel 349/350 (1912). S. 1-23.

Kraus, Karl. „Untergang der Welt durch schwarze Magie”. Schriften. Bd. 4: Untergang der Welt durch schwarze Magie. Red. Ch. Wagenknecht. Frankfurt a. M.: Suhrkamp, 1989. S. 424-454.

Kraus, Karl. Aforyzmy. Wybrał, przełożył i wstępem opatrzył M. Dobrosielski. Warszawa: Państwowy Instytut Wydawniczy, 1975.

Kraus, Karl. Die letzten Tage der Menschheit. Frankfurt a. M.: Suhrkamp, 1991.

Kraus, Karl. Gesammelte Glossen. Loschberg: Jazzybee Verlag, 2016.

Kraus, Karl. Pro domo et mundo. Hamburg: Severus, 2013.

Kraus, Karl. Schriften. Bd. 5: Gedichte. Red. Ch. Wagenknecht. Frankfurt a. M.: Suhrkamp, 1987.

Kraus, Karl. Schriften. Bd. 8: Aphorismen. Red. Ch. Wagenknecht. Frankfurt a. M.: Suhrkamp, 1986.

Kraus, Karl: „Antwort an Rosa Luxemburg von einer Unsentimentalen“. Die Fackel 554-556 (1920). S. 3-8. Kundera, Milan. Powolność. Przeł. Marek Bieńczyk. Warszawa: Państwowy Instytut Wydawniczy, 1997. Künzel, Christine. „Satiren (...) galten wie Bordellbesuche ausschließlich als Männersache'. Zur prekären Stellung der Satirikerin (am Beispiel Gisela Elsners)". Treibhaus. Jahrbuch für die Literatur der fünfziger Jahre 8 (2012). S. 99-114.

Listy Róży Luxemburg. Przekład z języka niemieckiego. Warszawa: Książka 1922.

Norberg, Jakob. "Creative Destruction: Karl Kraus and the Paradox of Satire” . Seminar 49, 1 (2003). S. 38-51.

Peiter, Anne D. Komik und Gewalt. Zur literarischen Verarbeitung der beiden Weltkriege und der Shoah. Köln/ Weimar/ Wien: Böhlau, 2007.

Pizer, John. „Modern vs. Postmodern Satire: Karl Kraus and Elfriede Jelinek”. Monatshefte 4 (1994). S. $500-513$.

Sax, Benjamin E. „Walter Benjamin's Karl Kraus: Negation, Quotation, and Jewish Identity”. Shofar: An Interdisciplinary Journal of Jewish Studies 32, 3 (2014). S. 1-29.

Steiner, George. „Introduction”. Benjamin, Walter. The Origin of German Tragic Drama. Przeł. John Osborne. London-New York: Verso, 1991.

Szczepaniak, Monika. „Monologi Kasandry”. Elfriede Jelinek, Podróż zimowa (program teatralny). Wrocław: Teatr Polski, 2014. S. 4-15.

Timms, Edward. Karl Kraus. Apocalyptic Satirist. Culture and Catastrophe in Habsburg Vienna. New Haven-London: Yale University Press, 1986.

Vogel, Juliane. „Intertextualität”. Jelinek-Handbuch. Red. P. Janke. Stuttgart-Weimar: Metzler, 2013. S. 47-55. 
MONIKA SZCZEPANIAK, LUDO-ŻERCY DOBRO-CZYŃCY. KARL KRAUS I ELFRIEDE JELINEK

Winter, Riki. Rozmowa z Elfriede Jelinek. Dossier 2: Elfriede Jelinek. Red. K. Bartsch, G.A. Höfler. GrazWien: Droschl, 1991. S. 9-19.

Wojnicka, Katarzyna. „Otto Weiniger: mizogin i profeminista? ”. Autobiografia. Literatura Kultura. Media 1 (6) 2016. S. 39-58. 